Keywords: bull riding; periodization; conditioning; strength training; rodeo

\title{
Bull Riding: Analysis and Application of a Specific Strength and Conditioning Program
}

Mark R. Barrett, MKin, CSCS

Strong Cowboy Strength and Conditioning, Calgary, Alberta, Canada

Dale J. Butterwick, MS, CAT; David J.Smith, PhD

University of Calgary, Alberta, Canada

\section{s u m m a r y}

Because bull riding is one of the most dangerous of extreme sports, it is very important to make efforts to improve the safety and the performance of its participants. A strength and general physical fitness program will better prepare riders for the demands of bull riding. The purpose of this paper is to describe the physiological demands of bull riding and to introduce a periodized strength and general fitness model.

\section{Introduction}

he sport of bull riding has been described as the "most dangerous 8 seconds in sport," so it is of no surprise that it has the highest rate of injury of all the major events in professional rodeo (5). Although each bull ride is highly unpredictable, the bull rider must combine mental focus, technical ability, and strength to have a successful ride of 8 seconds. A high score is not the only concern for the bull rider. Safety and the ability to dismount and move quickly from harm's way are key components within the context of bull riding. It seems logical to suggest that a stronger and well-conditioned bull rider would be better prepared and potentially more successful (and less likely to sustain injury) than a bull rider who does no training at all. Meyers et al. (6) and Tuza (15) agree that a preseason training program could prevent injury and greatly improve in-season training and performance. Therefore, it is the aim of this paper to present a yearly training model for a professional bull rider in order to improve performance and potentially reduce the incidence of injuries sustained during bull riding events.

\section{Biomechanics}

The objective of a bull rider is to stay centered on the bull's back (behind its shoulders). This is where the bull rider will position his bull rope behind the shoulders of the bull and center his grip for his riding arm to hold. He tries to stay forward (hips flexed) in this position for the duration of the bull ride. A bull rider watches the shoulders of the bull (looking slightly down) to try to anticipate and then react to the motion of the bull. A rider is only allowed to use 1 hand to hold the bull rope and does so with a supinated grip. When first sliding onto the back of the bull in the chute, a rider places the bull rope in the palm of the riding hand with the arm slightly flexed (approximately $50-70^{\circ}$ ) at the elbow. Although individual technique may vary slightly, he moves up on the bull as close to his riding hand as possible. His upper legs are forced into abduction, depending on the width of the bull's back, and his knees will be slightly flexed.

When a bull rider signals to open the chute, the bull is free to buck and move into the arena. It is at this point that a bull rider must react instantaneously as the bull lurches forward into the arena. This requires powerful bicep flexion, shoulder stabilization (of the riding arm), isometric activation of the abdominals and spinal erectors, adduction of the legs at the knees, and hamstring flexion. As mentioned, each bull ride is very unpredictable. However, bull riders study each bull very closely and often know the movement tendencies (spinning direction, bucking motion). His free arm is held up in the air and is used 
for balance and for correcting body position (Figure 1). Maximal isometric, concentric, and eccentric muscle contractions are all thought to occur in the upper and lower extremities as well as the trunk area. The major muscle actions that occur during a bull ride are theorized to be elbow flexion-extension, shoulder stabilization, trunk flexion-extension, hip flexion-extension, thigh adduction, and knee flexion and extension.

\section{Spinning}

A bull will spin so that its forelegs jump left or right followed by the hind legs. This makes it difficult for the bull rider to stay centered because this motion pulls him to the outside of the spin. A bull rider must use his inside leg and riding arm to counteract the motion of falling outside of the bull. At the same time, a bull rider must reset his other leg (extension of the knee, adduction of the hip to the front shoulder of the bull) to keep a stable position. Both actions involve using his spurs and knee to gain leverage (adduction of the leg). Some bull riders will use their knees more than their spurs when the bull spins, and others do the opposite. A bull can spin left or right and may switch directions during the bull ride. Depending on the riding hand of the bull rider, the bull will spin away from his hand or into his hand. For example, spinning away from his hand, a bull will spin left (counterclockwise) from a right-handed bull rider. Spinning into the hand happens when a bull spins in the direction of the riding hand of the bull rider (clockwise into a right-handed bull rider). Spinning away is more difficult because it instantly puts the bull rider in an unfavorable position: on the outside of the spin where the centripetal force is greater. Therefore, the bull rider must work harder to stay centered on the bull than if the bull was to spin into his hand.

\section{Bucking}

A bull will buck so that the forelegs are lower than the hind legs (head lower than

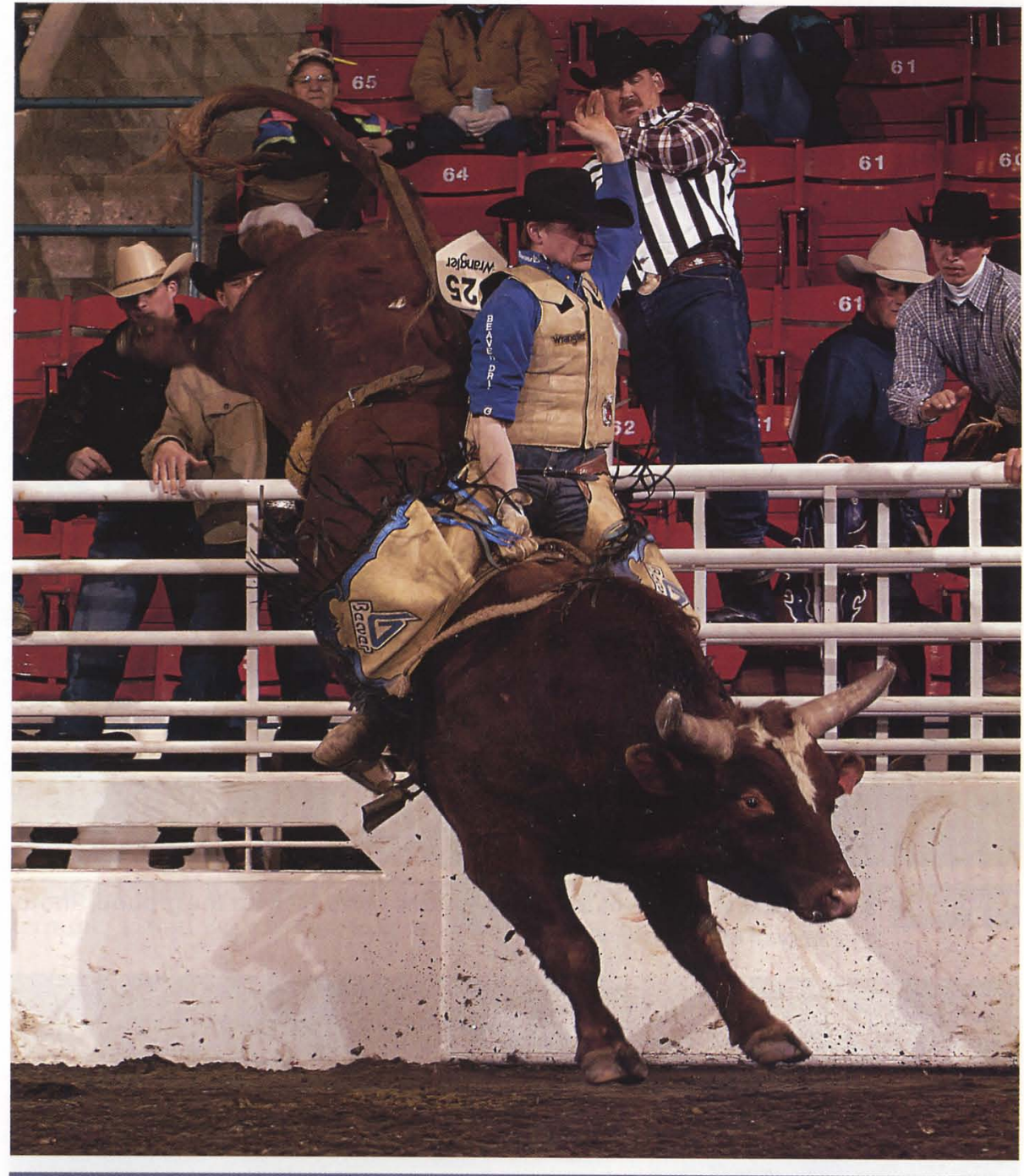

Figure 1. Maximal isometric, concentric, and eccentric muscle contractions are all thought to occur in the upper and lower extremities, as well as the trunk area, during a bull ride. Photo courtesy of Mike Copeman.

the rear end). The bull will buck with alternate foreleg-hind leg contact with the ground combined with a jumping motion (Figure 2). As this motion continues, it can draw the torso of a bull rider down and back, causing trunk flexion and extension. He must use his abdominal and low back muscles along with the hip flexors to counteract the forward and backward movement of the bull. This will involve both maximal isometric and eccentric contractions in this area. Counteracting this motion is of great importance because it will potentially prevent contact of a bull rider's head with the shoulder or head of the bull.

\section{Dismount}

When the horn sounds indicating that the rider has completed an 8-second ride, a rider must prepare to dismount the bull. The free hand is used to release the bull rope from the riding hand, which can put the rider in an unstable position (Figure 3 ). Once the rope is released, a rider will attempt to swing his leg (opposite to riding arm) over the shoulder of the bull and may lean back to let the hindquarters of the bull push him away from the animal. If the rider has fallen awkwardly, he must spring to his feet as quickly as possible and sprint away from the bull 


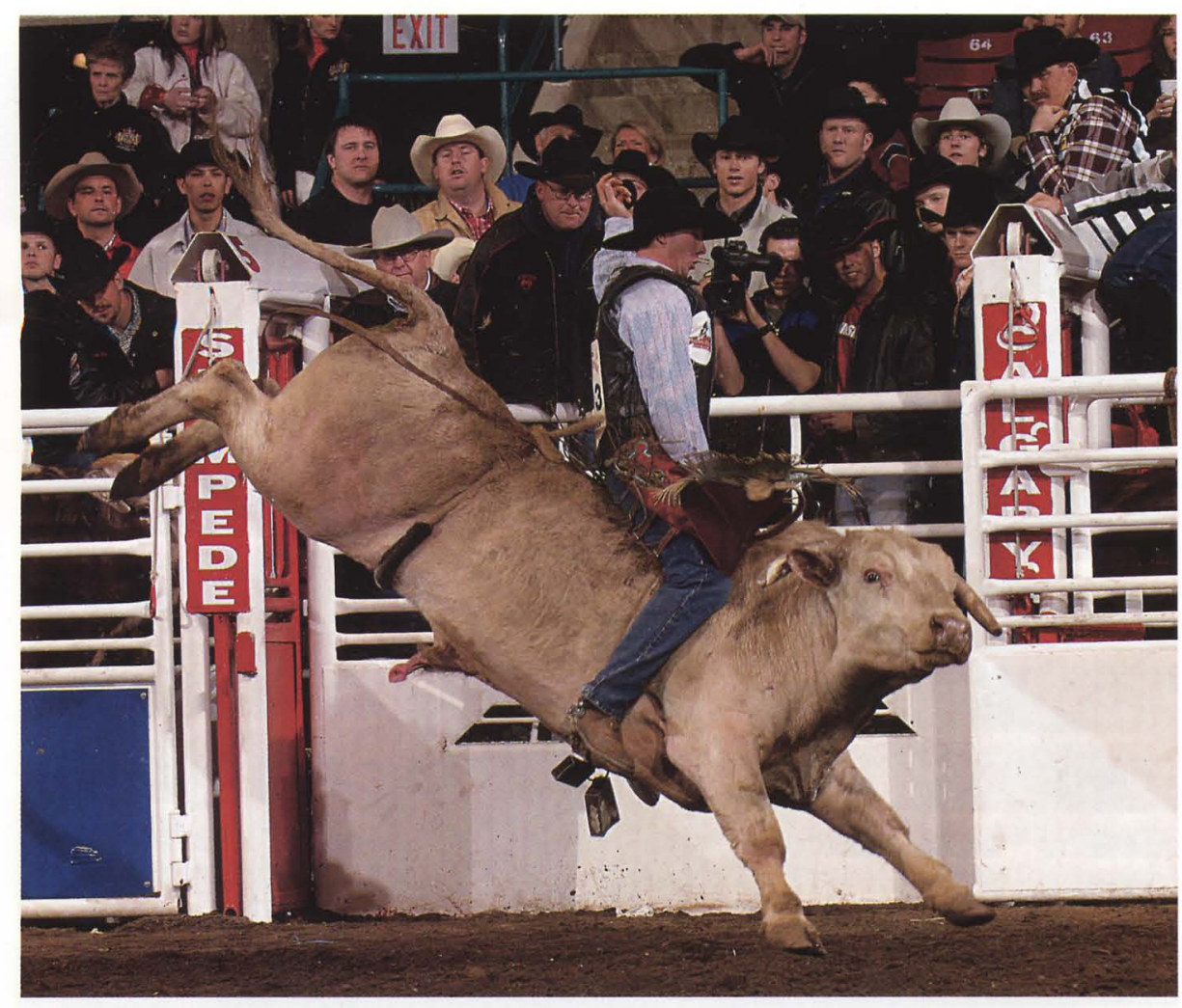

Figure 2. A bull bucks with alternate foreleg/hind leg contact with the ground. Photo courtesy of Mike Copeman.

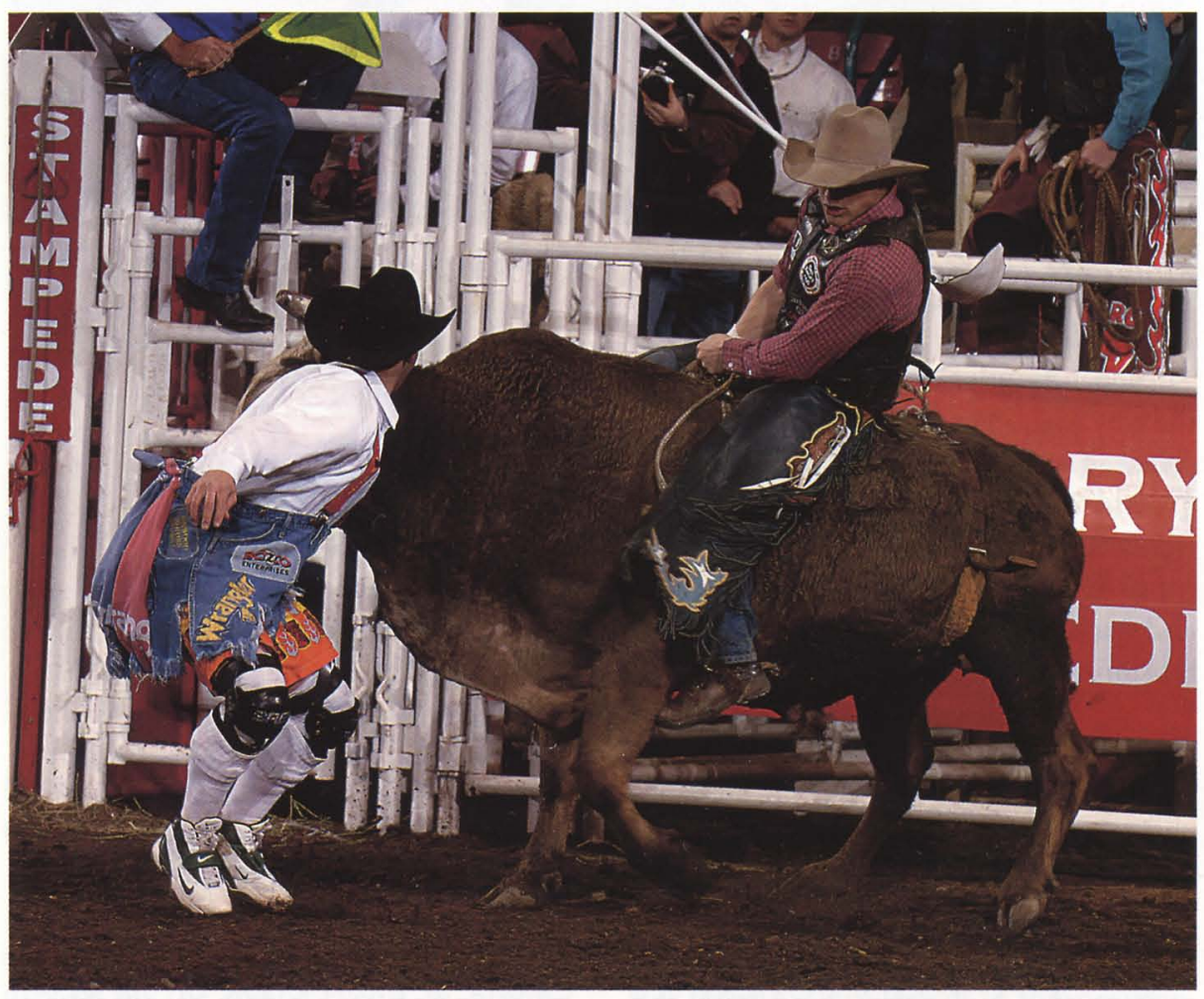

Figure 3. A bull rider attempts a dismount. Photo courtesy of Mike Copeman. in order to avoid contact with the animal.

\section{Injuries in Bull Riding}

In the sport of bull riding it is not a question of if you will be injured, it is more accurately when and how severely. Completely eliminating injuries in professional bull riding is unrealistic. The incidence of injury associated with bull riding has been shown to be 2 times higher than that of any of the other rodeo events (2). In a 5-year prospective study, Butterwick and Meeuwisse (4) reported bull riding injuries in Canadian Professional Rodeo from 1995 to 1999. One hundred forty-one injuries were recorded and categorized as minor, severe, and other (Figure 4). Common sites of injury were hands (fractures), groins (strains and ruptures), biceps (strains and ruptures), and shoulders (dislocations and subluxations). There were fractures caused by impact with the ground or contact with the bull (horns and hooves). Concussions and head injuries as a result of contact with the ground or bull are also common and are often underreported (5). The injury potential of this kind of contact is very serious and can be fatal. Three fatalities as a result of this contact (as well numerous concussions, neurological disorders, and parapalegia) have been documented in recent years in North America (3).

However, more than half of all injuries to bull riders were mild and moderate strains and contusions (5). It may be possible to influence the rate of muscular strain injury by conditioning. Because most of these injuries occur at or in conjunction with connective tissues, it is reasonable to believe that changing the size, density, or mechanical properties of the connective tissue framework will help to reduce the risk of injury (10). According to Nebergall (7), 70\% of rodeo injuries happen on the dismount. A stronger bull rider with good general physical fitness (GPF) may be better prepared to make the 8 -second time limit more often and able to dis- 
mount the bull on his own accord rather than be bucked off unexpectedly.

\section{Physiological Analysis}

As previously mentioned, a successful bull ride lasts 8 seconds. However, there is the possibility of a rider being bucked off well before the 8-second mark or being hung up and not able to dismount or get free of the bull rope. Regardless of these circumstances, the energy required during a bull ride comes predominantly from the adenosine triphosphate, creatine phosphate system with assistance from anaerobic glycolysis. Strength, power, and speed of movement are critical areas of concern for successful performances as a bull rider. Furthermore, balance, reaction time, and specific strength unique to bull riding are also very important. $\mathrm{Al}$ though aerobic fitness is not seen to be a major component of bull riding, an appropriate level of general physical fitness achieved by engaging in different whole body activities in the context of circuit-type training is important for the recovery process and allows for a larger capacity of training volume and intensity (9).

\section{Competition Schedule}

Professional bull riders have a very demanding competition schedule. There were events scheduled for 28 of the 52 weeks of the 2003-2004 competition year. The most intense part of the year happens between the second week of January and the last week of April. During this period, a bull rider may compete every weekend for 18 straight weeks (barring injury). The competition schedule allows for periods of rest $(5 \times 3$-week periods $)$ with significant weeks without competition during the summer months (May to September). During these months there are only 4 events scheduled. However, bull riders can enter summer rodeos or other bullriding events to earn extra money.

Bull riding events generally take place on Saturday and Sunday nights in vari-

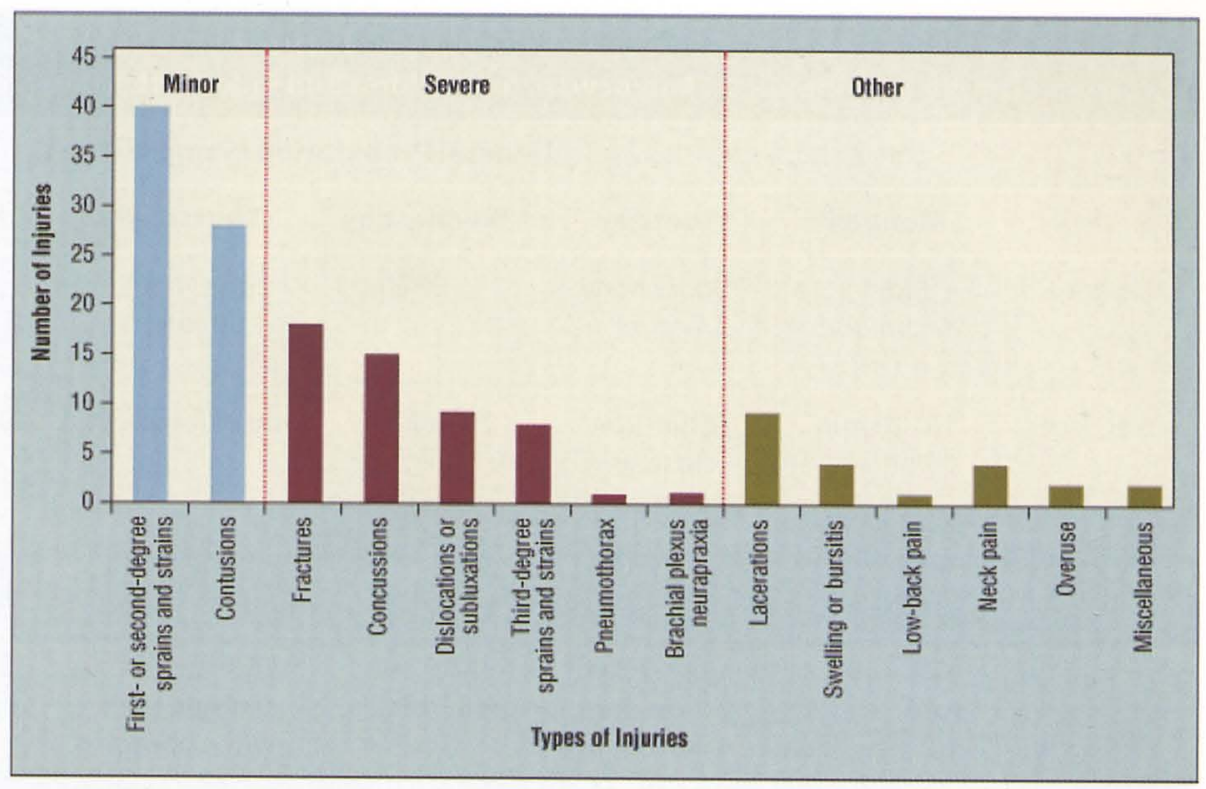

Figure 4. Bull riding injuries in professional rodeo in Canada (1995-1999). ous cities throughout the United States. A bull rider will typically ride 1 time per night on the first day of a 2-day competition but may have the option of riding twice in 1 night (reride) if the judges determine a foul was committed or the bull did not perform properly. On the second day of a 2-day competition (or in a 1-day competition), the top 10 placing riders will ride twice that day. Rest time between these rides can vary from 30 to 60 minutes.

\begin{tabular}{|c|c|c|c|}
\hline \multicolumn{4}{|c|}{$\begin{array}{c}\text { Table } 1 \\
\text { Periodized Training Schedule }\end{array}$} \\
\hline Week & Length (weeks) & Month & Mesocycle/Training Phase \\
\hline 1 & 1 & November & Active rest \\
\hline $2-4$ & 3 & November & General preparation \\
\hline $5-7$ & 3 & December & Specific preparation 1 \\
\hline $8-25$ & 18 & January-April & Maintenance and recovery* \\
\hline 26 & 1 & April & Active rest \\
\hline $27-32$ & 6 & May-June & General preparation \\
\hline $33-34$ & 2 & June & Maintenance and recovery* \\
\hline $35-38$ & 4 & June-July & Specific preparation 1 \\
\hline $39-42$ & 4 & July-August & Specific preparation 2 \\
\hline $43-45$ & 3 & August-September & Taper \\
\hline $46-52$ & 7 & September-October & Competition/World Finals* \\
\hline $\begin{array}{l}\text { *Pha: } \\
\text { based o } \\
\text { compet }\end{array}$ & $\begin{array}{l}\text { uring which the bu } \\
2003-2004 \text { comp } \\
\text { schedule. }\end{array}$ & $\begin{array}{l}\text { ider is competing for } 2 \mathrm{C} \\
\text { ition year and represent }\end{array}$ & $\begin{array}{l}\text { ore consecutive weekends, } \\
\text { typical Built Ford Tough Series }\end{array}$ \\
\hline
\end{tabular}


Table 2

Sample Training Week (Microcycle) to Provide a Bull Rider with a Base Level of Strength and Endurance

\begin{tabular}{|c|c|c|c|c|c|c|c|}
\hline \multicolumn{8}{|c|}{ General Preparation (Sample Week) } \\
\hline & Monday & Tuesday & Wednesday & Thursday & Friday & Saturday & Sunday \\
\hline Workout & $\begin{array}{l}\text { Riding } \\
\text { technique } \\
\text { + GPT }\end{array}$ & $\begin{array}{l}\text { Upperbody } \\
+ \text { core }\end{array}$ & GPT & $\begin{array}{l}\text { Lower body } \\
+ \text { core }\end{array}$ & GPT & $\begin{array}{l}\text { Upperbody } \\
\text { + core }\end{array}$ & Rest \\
\hline \multirow[t]{5}{*}{ Exercises } & $15-20 \mathrm{~min}$ & $\begin{array}{l}\text { Chin-ups } \\
\text { (close grip } \\
\text { supinated) }\end{array}$ & $20-30 \mathrm{~min}$ & Squat/leg press & $20-30 \mathrm{~min}$ & $\begin{array}{l}\text { Chin-ups } \\
\text { (supinated) }\end{array}$ & \\
\hline & $\begin{array}{c}@ 60-75 \% \\
\max . H R\end{array}$ & Bench press & $\begin{array}{c}\text { @60-75\% } \\
\max . \mathrm{HR}\end{array}$ & $\begin{array}{l}\text { Independent } \\
\text { ham curl }\end{array}$ & $\begin{array}{c}@ 60-75 \% \\
\max . H R\end{array}$ & Bench press & \\
\hline & $\begin{array}{l}\text { (Bike, run, } \\
\text { rollerblade, } \\
\text { etc.) }\end{array}$ & $\begin{array}{l}\text { Independent } \\
\text { shoulder } \\
\text { shrugs }\end{array}$ & $\begin{array}{l}\text { (Bike, run, } \\
\text { rollerblade, } \\
\text { etc.) }\end{array}$ & $\begin{array}{l}\text { Adduction } \\
\text { (single leg } \\
\text { with tubing) }\end{array}$ & $\begin{array}{l}\text { (Bike, run, } \\
\text { rollerblade, } \\
\text { etc.) }\end{array}$ & $\begin{array}{l}\text { Independent } \\
\text { shoulder } \\
\text { shrugs }\end{array}$ & \\
\hline & & $\begin{array}{l}\text { Seated } 1 \text {-arm } \\
\text { rows }\end{array}$ & & & & $\begin{array}{l}\text { Seated } 1 \text {-arm } \\
\text { rows }\end{array}$ & \\
\hline & & Dips & & & & Dips & \\
\hline $\begin{array}{l}\text { Resistanc } \\
\text { internal an } \\
\text { will be reve } \\
\text { cal training }\end{array}$ & $\begin{array}{l}\text { ercises will con } \\
\text { ernal rotation e } \\
\text { so that } 2 \text { lower }\end{array}$ & $\begin{array}{l}\text { of } 3 \text { sets of } 10-1 \\
\text { rcises }(3 \times 15) \text {. Res } \\
\text { dy workouts will }\end{array}$ & $\begin{array}{l}\text { repetitions with } t \\
\text { between sets of } \\
\text { e completed.May }\end{array}$ & $\begin{array}{l}\text { ach exercise is } 75 \mathrm{se} \\
\mathrm{HR}=\text { maximum hea }\end{array}$ & $\begin{array}{l}\text { re and adductic } \\
\text { nds. The follow } \\
\text { rate determine }\end{array}$ & $\begin{array}{l}\text { exercises }(3 \times 15) \\
\text { week, the resista } \\
\text { by } 220 \text {-age);GPT }\end{array}$ & $\begin{array}{l}\text { he shoulde } \\
\text { workouts } \\
\text { neral physi }\end{array}$ \\
\hline
\end{tabular}

\begin{tabular}{|c|c|c|}
\hline \multicolumn{3}{|c|}{$\begin{array}{l}\text { Table } 3 \\
\text { Sample Core Workouts to Be Used Within Training Microcycles }\end{array}$} \\
\hline Core 1 (Sample) & Core 2 (Sample) & Core 3 (Sample) \\
\hline Decline weighted sit up & Lateral raise (obliques) & Decline leg lifts/lower \\
\hline Weighted back extension & Reverse back extension & Trunk twist (with cable) \\
\hline Decline trunk twist (with ball) & Medicine ball throw (overhead) & Medicine ball throw (lateral) \\
\hline Internal-external shoulder rotation & Internal-external shoulder rotation & Internal-external shoulder rotation \\
\hline \multicolumn{3}{|c|}{$\begin{array}{l}\text { These core workouts are to be carried out after the resistance workout and completed as a circuit. Two sets of } 15-30 \text { repetitions should be per- } \\
\text { formed for each exercise during each mesocycle. However, the resistance may be increased and the repetitions decreased as the bull rider reach- } \\
\text { es the specific preparation/taper phases. There should be little rest (10-15 seconds) between each exercise. However, there should be } 3 \text { minutes } \\
\text { of rest between each circuit. }\end{array}$} \\
\hline
\end{tabular}

All healthy riders ride in every professional bull riding event. The top 45 are required to ride if they are healthy; otherwise they are replaced and suspended. Thus, in addition to the significant monetary incentives to compete at every professional event, there are penalties for not doing so when you are eligible.

Extensive travel is required to get to each event. The World Finals take place in Las Vegas, NV, in late November, which follows another intense string of competitions (3) followed by a week of rest.

\section{Performance Goals and Training}

Consistency is the key to success in bull riding from both a financial and a physiological point of view. Each bull riding event during the season is equally im- portant. Scoring points by performing well at each event will help ensure a spot at the World Finals. Therefore, GPF and muscular endurance should be emphasized for a period in order to improve the rider's recovery ability. According to Bompa (1), athletes need multilateral physical development as a training base, as well as overall physical fitness. The higher the working potential of the athlete, the more easily the body adapts to 


\begin{tabular}{|c|c|c|c|c|c|}
\hline \multicolumn{6}{|c|}{$\begin{array}{c}\text { Table } 4 \\
\text { Sample Technical Workouts Performed on Mechanical Bulls }\end{array}$} \\
\hline \multicolumn{3}{|c|}{ Riding Technique (Sample 1) } & \multicolumn{3}{|c|}{ Riding Technique (Sample 2) } \\
\hline Exercise & Set & Rest & Exercise & Set & Rest \\
\hline $\begin{array}{l}\text { Start without warning } \\
(5 \times 5 \text {-s bursts })\end{array}$ & $3 \times 5$ & $1 \mathrm{~min}$ & Legs only (20 s) & 4 reps & $1 \mathrm{~min}$ \\
\hline Dismounts & $3 \times 4$ reps & $1 \mathrm{~min}$ & Blindfolded (15s) & 4 reps & $1 \mathrm{~min}$ \\
\hline 3 full rides (14s) & 3 & $\begin{array}{l}3 \text { min active } \\
\text { recovery }\end{array}$ & $\begin{array}{l}\text { Recovery exercises (into } \\
\text { hand-away from hand) }\end{array}$ & 5 from each side & $1 \mathrm{~min}$ \\
\hline \multicolumn{6}{|c|}{$\begin{array}{l}\text { Start without warning:The bull rider has no forewarning of when the bull will start bucking. He is forced to react quickly to the action of the } \\
\text { bull. Dismounts: The bull rider is to practice the dismount from both spinning directions. The bull will be in the bucking motion, and the bull rider } \\
\text { will pull on the bull rope to release it and perform a proper dismount. Full rides:The bull rider will ride the mechanical bull for } 14 \text { seconds at a } \\
\text { predetermined difficulty level. Legs only: The bull rider will be forced to use his legs for stability. The riding arm is allowed to touch the top of the } \\
\text { bull, but the bull rider may not use his bull rope at all. Blindfolded: Extreme caution should be taken here so as not to make it too difficult too } \\
\text { soon. The bull rider will be blindfolded and therefore forced to use his sensory perception in both upper and lower body to stay on top. The } \\
\text { difficulty should be fairly low to start to allow the bull rider to get accustomed to this exercise. Recovery exercises:The bull rider deliberately gets } \\
\text { himself out of position ( } 5 \text { times from each side away from his riding hand and into his riding hand.). The bull is then to start bucking, and the bull } \\
\text { rider must try to get himself back into position using his arm and legs. }\end{array}$} \\
\hline
\end{tabular}

the continuous increase in physical and psychological training and competition demands.

Although bull riding is a single high-intensity event, training with live (and mechanical) bulls is high-intensity intermittent exercise, during which a rider may perform multiple rides or sets. The literature suggests that cardiovascular fitness enhances recovery from high-intensity intermittent exercise through increased aerobic response and enhanced phosphocreatine regeneration (12). According to Thoden (14), possessing a good cardiovascular level of fitness may enhance the ability of the muscle to recover after anaerobic exercise. Theoretically, an increase in cardiovascular fitness could enhance recovery by providing aerobically derived energy at a faster rate during the recovery period. Additionally, any improvements that aid in transport to or from the muscle, such as increased blood flow, could enhance the removal of lactic acid and heat (13). Furthermore, GPF may prevent stress-induced suppression of the immune system, reducing the increased susceptibility and severity of infectious diseases caused by stress (6).
However, training should focus on maximal strength, specific strength, power, and speed during periods away from competition. It is known that a large degree of strength improvement will come not only from cellular adaptations but also from neural adaptations, such as increased activation of motor units and coordination of prime movers, synergists, and antagonists (8).

In order to achieve the aforementioned physical requirements for successful bull riding, a training model is presented in which these specific training adaptations will be sought. It should be noted that although this is a yearly plan, it is anticipated that it can be used and adapted over consecutive years to allow a positive progression of strength and conditioning of a professional bull rider.

\section{Strength and Conditioning Program for Bull Riders}

The training program is periodized based on systems outlined from Bompa (1; Table 1). Evidence suggests that periodized programs are superior to improving strength and power even over a short period (11). This is done by manipulating training variables within specific periods. These workable periods are called macro-, meso-, and microcyles. Macrocycles can be 1 to 6 months long, depending on the sport and competition schedule, whereas mesocycles are generally 3 to 6 weeks long. Within mesocycles are microcycles that generally have a duration of 3 to 7 days. These are the most important functional tools of planning because their structure and content determine the quality of training (1).

In the periodized plan for bull riders, mesocycles of 3 to 4 weeks are used, with the exception of the large maintenance phase. Weeks of active rest are inserted after intense periods of the competition year. During the months of January to April, 2 weeks in June, and the 4 weeks leading up to the World Finals, the bull rider is to follow a maintenance phase. During the active rest and maintenance phases, recovery strategies are emphasized.

A general preparation phase is recommended at the end of April followed by 2 weeks of maintenance during competition. Then specific training adaptations are sought during 2 specific preparation phases ( 4 weeks each) in 


\begin{tabular}{|c|c|c|c|c|c|c|c|}
\hline \multicolumn{8}{|c|}{$\begin{array}{l}\text { Table } 5 \\
\text { Sample Training Week (Microcycle) to Improve a Bull Rider's Maximum Strength }\end{array}$} \\
\hline \multicolumn{8}{|c|}{ Specific Preparation 1 (Sample Week) } \\
\hline & Monday & Tuesday & Wednesday & Thursday & Friday & Saturday & Sunday \\
\hline \multicolumn{8}{|l|}{ Workout } \\
\hline$A M$ & $\begin{array}{l}\text { Riding } \\
\text { technique }\end{array}$ & GPT & & GPT + core & & & Rest \\
\hline PM & & $\begin{array}{l}\text { Upperbody } \\
\text { +core }\end{array}$ & Lower body & & Speed work & $\begin{array}{l}\text { Upperbody } \\
+ \text { core }\end{array}$ & \\
\hline \multirow[t]{4}{*}{ Exercises } & & $\begin{array}{l}\text { Standing bent } \\
\text { rows }\end{array}$ & Deadlift & & $\begin{array}{l}5 \times 15-m \text { sprint } \\
\text { from prone }\end{array}$ & $\begin{array}{l}\text { Standing bent } \\
\text { rows }\end{array}$ & \\
\hline & & $\begin{array}{l}\text { Seated Row on } \\
\text { Ball with rope }\end{array}$ & Side lunges & & $\begin{array}{l}5 \times 15-m \text { sprint } \\
\text { from supine }\end{array}$ & $\begin{array}{l}\text { Seated row on } \\
\text { ball with rope }\end{array}$ & \\
\hline & & $\begin{array}{l}\text { Incline dumbbell } \\
\text { press }\end{array}$ & $\begin{array}{l}\text { Adduction } \\
\text { straight-bent leg }\end{array}$ & & $\begin{array}{l}3 \times 25-\mathrm{m} \text { sprint } \\
\text { pulling tire }\end{array}$ & $\begin{array}{l}\text { Incline dumbbell } \\
\text { press }\end{array}$ & \\
\hline & & Weighted dips & & & & Weighted dips & \\
\hline $\begin{array}{r}\text { Resistan } \\
\text { internal/ex } \\
\text { week, the } r\end{array}$ & $\begin{array}{l}\text { xercises will } \\
\text { hal rotation }\end{array}$ & $\begin{array}{l}\text { sist of } 4 \text { sets of } 5-8 \text { re } \\
\text { lunging exercises }(3\end{array}$ & $\begin{array}{l}\text { oetitions at approxim } \\
\text { ets of } 15) \text {. Rest betwe }\end{array}$ & tely $80-85 \% 1 F$ & $\begin{array}{l}\text { A with the exceptio } \\
\text { inutes to allow ade }\end{array}$ & $\begin{array}{l}\text { f the adduction and st } \\
\text { ate recovery. The follo } \\
\text { ysical training. }\end{array}$ & $\begin{array}{l}\text { oulder } \\
\text { ving }\end{array}$ \\
\hline
\end{tabular}

July and August. A period of reduced training or taper is then carried out in late August and the first 2 weeks of September in order to peak for the competitions in September and the World Finals in October. During this competition phase, rest, recovery, and regeneration are the focuses to optimize performance.

\section{General Preparation}

The general preparation mesocycle (Table 2) of 6 weeks provides GPF to a bull rider and will serve as a platform to progress to the next few mesocycles. Establishing a proper foundation of muscular strength and endurance is the goal of this phase, as well as an introduction to basic resistance training exercises (when required) to provide the background for more advanced and intensified training later in the year. Resistance training is carried out 3 times a week together with 2 cardiovascular workouts. Upper-lower body resistance workouts are alternated throughout the mesocycle. GPF is performed to improve the bull rider's recovery process in times of high-vol- ume, high-intensity training or during competition. Resistance exercises that promote shoulder stability are stressed because shoulder injuries are a common site of injury for bull riders (5). Also, core (abdominal, low back) exercises are performed 3 times a week because core strength is thought to be essential to performance as well as injury prevention in bull riding (Table 3). A technique workout is also inserted to allow a bull rider to practice exercises specific to bull riding (Table 4). This workout could be done on a mechanical bull or equipment that would simulate a bull ride (potentially fitballs).

\section{Specific Preparation 1}

The goal of the specific preparation 1 mesocycle (Table 5) is to increase a bull rider's maximum strength in both the upper and the lower body. However, maintenance of the smaller muscles (internal-external rotators of the shoulder, adductors of the legs) is continued during this phase. Resistance training is carried out 3 times a week. However, the loading parameters and exercises are different from those in the previous mesocycle. One repetition maximum (1RM) tests for resistance exercises are carried out prior to this phase to determine loading parameters. A general warm-up of $10 \mathrm{~min}$ utes should precede each resistance workout, and a 10-minute cooldown with flexibility exercises should follow. A speed workout is inserted into this mesocycle to improve a bull rider's speed after a dismount or being bucked off. This mesocycle is 4 weeks in duration.

\section{Specific Preparation 2}

Building on the strength gains from specific preparation 1 , the specific preparation 2 mesocycle (Table 6) aims to improve a bull rider's power and specific strength associated with bull riding. 1RM tests for resistance exercises are carried out prior to this phase to determine loading parameters. Power workouts incorporate both upper- and lower-body exercises and are done 2 times a week. The ability to produce power in both the upper and the lower body by counter- 


\begin{tabular}{|c|c|c|c|c|c|c|c|}
\hline \multicolumn{8}{|c|}{$\begin{array}{c}\text { Table } 6 \\
\text { Sample Training Week (Microcycle) to Improve a Bull Rider's Pow }\end{array}$} \\
\hline \multicolumn{8}{|c|}{ Specific Preparation 2 (Sample Week) } \\
\hline & Monday & Tuesday & Wednesday & Thursday & Friday & Saturday & Sunday \\
\hline \multicolumn{8}{|l|}{ Workout } \\
\hline $\mathrm{AM}$ & $\begin{array}{l}\text { Riding } \\
\text { technique }\end{array}$ & & & GPT & & & Rest \\
\hline PM & & $\begin{array}{l}\text { Power workout } \\
+ \text { core }\end{array}$ & Speed work & & $\begin{array}{l}\text { Power workout } \\
+ \text { core }\end{array}$ & Speed work & \\
\hline \multirow[t]{4}{*}{ Exercises } & & $\begin{array}{l}\text { Weighted } \\
\text { jump squats }\end{array}$ & $\begin{array}{l}4 \times 10-\mathrm{m} \text { sprint } \\
\text { from prone with } \\
\text { tire }\end{array}$ & $20-30 \mathrm{~min}$ & $\begin{array}{l}\text { Single leg } \\
\text { lateral bounds }\end{array}$ & $\begin{array}{l}4 \times 10 \text {-m sprint } \\
\text { from prone with } \\
\text { tire }\end{array}$ & \\
\hline & & $\begin{array}{l}\text { Weighted } \\
\text { chin ups }\end{array}$ & $\begin{array}{l}4 \times 10-m \text { sprint } \\
\text { from supine } \\
\text { with tire }\end{array}$ & $\begin{array}{l}@ 60-70 \% \max . \\
\text { HR }\end{array}$ & $\begin{array}{l}\text { Explosive } \\
\text { shrugs }\end{array}$ & $\begin{array}{l}4 \times 10-m \text { sprint } \\
\text { from supine } \\
\text { with tire }\end{array}$ & \\
\hline & & $\begin{array}{l}\text { Clap } \\
\text { push-ups }\end{array}$ & $\begin{array}{l}3 \times 20-m \text { sprint } \\
\text { through pylons }\end{array}$ & $\begin{array}{l}\text { (Bike, run, } \\
\text { rollerblade, etc.) }\end{array}$ & $\begin{array}{l}\text { Medicine ball } \\
\text { heave }\end{array}$ & $\begin{array}{l}3 \times 20-m \text { sprint } \\
\text { through pylons }\end{array}$ & \\
\hline & & $\begin{array}{l}\text { Medicine ball } \\
\text { throws }\end{array}$ & & & & $\begin{array}{l}\text { Explosive } \\
\text { adduction }\end{array}$ & \\
\hline
\end{tabular}

\begin{tabular}{|c|c|c|c|c|c|c|c|}
\hline & Monday & Tuesday & Wednesday & Thursday & Friday & Saturday & Sunday \\
\hline \multicolumn{8}{|l|}{ Workout } \\
\hline PM & & $\begin{array}{l}\text { Split workout } \\
\text { +core }\end{array}$ & & Speed work & $\begin{array}{l}\text { Split workout } \\
+ \text { core }\end{array}$ & & \\
\hline \multirow[t]{3}{*}{ Exercises } & & Hang clean & $20-30 \mathrm{~min}$ & $\begin{array}{l}4 \times 10-m \text { sprint } \\
\text { from prone with } \\
\text { tire }\end{array}$ & Deadlift & & \\
\hline & & Lateral squat & $\begin{array}{l}@ 60-70 \% \max . \\
\text { HR }\end{array}$ & $\begin{array}{l}4 \times 10-m \text { sprint } \\
\text { from supine } \\
\text { with tire }\end{array}$ & $\begin{array}{l}\text { Weighted } \\
\text { lunges }\end{array}$ & & \\
\hline & & $\begin{array}{l}\text { Incline dumb- } \\
\text { bell press }\end{array}$ & & & Weighted dips & & \\
\hline
\end{tabular}

Resistance exercises will be done powerfully and dynamically similar to that of the previous mesocycle. Three to 4 sets of 3-6 repetitions will be completed for each exercise with the exception of the core exercises. Rest between sets will be 3-5 minutes to allow adequate recovery. Max. $\mathrm{HR}=$ maximum heart rate determined by 220 - age; GPT = general physical training. 
Table 8

Sample Training Week (Microcycle) to Allow the Bull Rider Recovery While Maintaining a High Level of Fitness

\begin{tabular}{|c|c|c|c|c|c|c|c|}
\hline \multicolumn{8}{|c|}{ Maintenance and Recovery-Competition (Sample Week) } \\
\hline & Monday & Tuesday & Wednesday & Thursday & Friday & Saturday & Sunday \\
\hline Workout & $\begin{array}{l}\text { Recovery- } \\
\text { Active Rest }\end{array}$ & $\begin{array}{l}\text { Split Workout + } \\
\text { Core }\end{array}$ & $\begin{array}{l}\text { Active Rest } \\
\text { (GPT) }\end{array}$ & $\begin{array}{l}\text { Riding } \\
\text { technique }\end{array}$ & Travel & Compete & $\begin{array}{l}\text { Compete-Travel } \\
\text { Rest-Recovery }\end{array}$ \\
\hline \multirow[t]{6}{*}{ Exercises } & $\begin{array}{l}\text { Hot-cold } \\
\text { baths }\end{array}$ & Lateral squat & Horse riding & & & & Hot-cold baths \\
\hline & Icing-heat & $\begin{array}{l}\text { Hamstring } \\
\text { curls }\end{array}$ & $\begin{array}{l}\text { Low intensity } \\
\text { games }\end{array}$ & & & & lcing-heat \\
\hline & Stretching & $\begin{array}{l}\text { Weighted chin } \\
\text { ups }\end{array}$ & $\begin{array}{l}\text { Jog-bike }<30 \\
\text { mins }\end{array}$ & & & & Stretching \\
\hline & Massage & $\begin{array}{l}\text { Dumbbell } \\
\text { press }\end{array}$ & & & & & Massage \\
\hline & $\begin{array}{l}\text { Range of } \\
\text { motion }\end{array}$ & & & & & & $\begin{array}{l}\text { Range of } \\
\text { motion }\end{array}$ \\
\hline & $\begin{array}{l}\text { Flexibility } \\
\text { exercises }\end{array}$ & & & & & & $\begin{array}{l}\text { Flexibility } \\
\text { exercises }\end{array}$ \\
\hline $\begin{array}{l}\text { The split } \\
\text { nal-externa } \\
\text { shoulder. R } \\
\text { will be vari } \\
\text { course of th }\end{array}$ & $\begin{array}{l}\text { out will cons } \\
\text { ation. Repetit } \\
\text { etween sets i } \\
\text { er the course } \\
\text { ek as needed }\end{array}$ & $\begin{array}{l}\text { f } 3 \text { sets for each ex } \\
\text { of } 8-10 \text { will be do } \\
\text { nins to allow recov } \\
\text { his mesocycle (eve } \\
T=\text { general physic }\end{array}$ & $\begin{array}{l}\text { ercise completing } \\
\text { ne for lateral squat } \\
\text { ery. Please note th } \\
\text { ery } 3-4 \text { weeks). Rec } \\
\text { al training. }\end{array}$ & $\begin{array}{l}\text { reps at } 90 \% \text { of } \\
\text { petitions of } 10 \\
\text { he exercises us } \\
\text { ry exercises (u }\end{array}$ & $\begin{array}{l}\text { M with the e } \\
5 \text { will be don } \\
\text { in the Split } \\
\text { dalone or in }\end{array}$ & $\begin{array}{l}\text { on of the latera } \\
\text { internal-exterr } \\
\text { ut and Riding t } \\
\text { ination) can be }\end{array}$ & $\begin{array}{l}\text { quats and inter- } \\
\text { rotation of the } \\
\text { hnique sections } \\
\text { one over the }\end{array}$ \\
\hline
\end{tabular}

acting the forces generated by the bull is crucial. A bull rider must be able to produce maximal force over a short period in order to be successful. Resistance exercises are performed quickly and dynamically. Therefore, plyometrics and medicine ball activities are utilized. Again, workouts include a warm-up and cooldown-flexibility exercises. A second speed workout is inserted during this phase. Dynamic and powerful core exercises are emphasized during this 4-week period in order to prepare a bull rider for such movements during bull riding.

\section{Taper}

In the taper mesocycle (Table 7), the aim is to fine-tune a bull rider's technique, maintain the intensity of training, and allow a reduction in any residual fatigue that may be present from previous weeks of training. Two technique workouts are to be completed along with 2 split workouts (resistance training). Resistance exercises are performed similarly to those in the previous mesocycle: dynamically and quickly. One speed workout is maintained during this phase. This mesocycle is 3 weeks in duration. It is expected that the combination of reduced volume, adequate rest, and specific technical training will leave the bull rider feeling fresh, rested, and confident when heading into the last few competitions and World Finals.

\section{Maintenance and Recovery- Competition}

The goal of the maintenance and recovery-competition phase (Table 8 ) is to maintain strength levels and allow recovery and regeneration so that a bull rider can compete each weekend. These periods in the yearly schedule present a challenge because a bull rider competes on consecutive week- ends, which allows little rest. Therefore, the week consists of 1 resistance workout, 1 technique workout, and 2 days of active rest-recovery and regeneration. 1RM tests for resistance exercises are carried out prior to this phase to determine loading par-ameters. Intensity is kept very high during these workouts to keep a bull rider sharp and primed for competition. However, the volume of training is relatively low to allow adequate recovery. Recovery and regeneration exercises include hot-cold baths, massage, iceheat, and range of motion-flexibility exercises.

\section{Conclusion}

This periodized model may be useful to a bull rider competing in professional bull rides or at a high level of competition. Technical instruction and supervised training will ensure that exercises are performed properly and that injuries 
as a result of training are minimized. This training model, combined with a dedicated and determined athlete, will promote athlete preparation and appropriate peaking of performance during the bull riding season.

\section{References}

1. Bомpa, T.O. Periodization: Theory and Methodology of Training (5th ed.). Windsor, Ontario: Human Kinetics, 1999. pp. 5-6, 165-185.

2. Brandenburg, M.A, and P. Archer. Survey analysis to assess the effectiveness of the Bull Tough Helmet in preventing head injuries in bull riders: A pilot study. Clin. J. Sports Med. 12: 360-366. 2002.

3. Butterwick, D.J., B. Hagel, D.S. Nelson, M.R. LefaVe, and W.H. MeEUWISSE. Epidemiological analysis of injury in five years of Canadian professional rodeo. Am. J. Sports Med. (2):193-198. 2002.

4. ButTerwick, D.J., AND W.H. Meeuwisse. Bull riding injuries in professional rodeo. Phys. Sports Med. 31(6):37. 2003.

5. Butterwick, D.J., AND W.H. Meeuwisse. Effect of experience on rodeo injury. Clin. J. Sport Med. 12: 30-35. 2002.

6. Fleshner, M. Physical activity and stress resistance: Sympathetic nervous system adaptations prevent stress-induced immunosuppression. Exerc. Sport Sci. Rev. 33(3):120-126. 2005.

7. Meyers, M.C., J.G. WilKinson, J.R. Elledge, H. Tolson, and J.C. STERLING. Exercise performance of collegiate rodeo athletes. Am. J. Sports Med. 20:410-415. 1992.

8. Nebergall, R.W., J.M. Bauer, and R.M. EImEn. Rough riders: How much risk in rodeo? Phys. Sports Med. 20(10):85-92. 1992.

9. SALE, D.G. Neural adaptation to resistance training. Med. Sci. Sports Exerc. 20(5)Suppl.: S135-S145. 1998.

10. SмIтн, D.J. A framework for understanding the training process leading to elite performance. Sports Med. 33(15):1103-1126. 2003.
11. Stone, M.H. Muscle conditioning and muscle injuries. Med. Sci. Sports Exerc. 22:457-462. 1990.

12. Stone, M.H., H.S. O’Bryant, B.K. SChilling, R.L. Johnson, K.C. Pierce, G.G. Haff, A.J. Koch, and M.E. Stone. Periodization. Part 1: Effects of manipulating volume and intensity. Strength Cond. J. 21(2):56-62. 1999.

13. Tomlin, D.L., And H.A. Wenger. The relationship between aerobic fitness and recovery from high intensity intermittent exercise. Sports Med. 31(1):1-11. 2001.

14. Thoden, J.S. Testing aerobic power. In: Physiological Testing of the High-Performance Athlete. J.D. MacDougall, H.A. Wenger, and H.J. Green, eds. Champaign, IL: Human Kinetics, 1991. pp. 107-174.

15. TuZA, G. Training considerations for rodeo. NSCA J. 6:38-41. 1995.

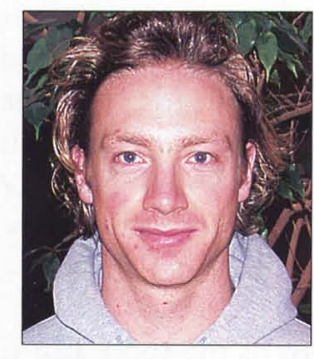

Barrett

Mark Barrett is the Director of Strong Cowboy Strength and Conditioning in Calgary, Alberta, Canada.

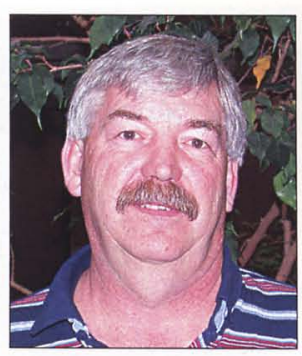

Butterwick

Dale Butterwick is a senior instructor in athletic therapy at the University of Calgary and President of the Canadian Pro Rodeo Sports Medicine Team in Calgary, Alberta, Canada.

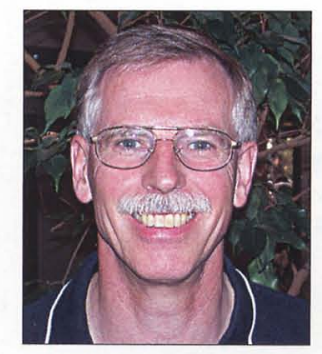

Smith

David J. Smith is a professor of applied exercise physiology in the Faculty of Kinesiology at the University of Calgary and director of Sport Science at the Canadian Sport Centre, Calgary, Alberta, Canada.

\section{Embroidered Briefcase}

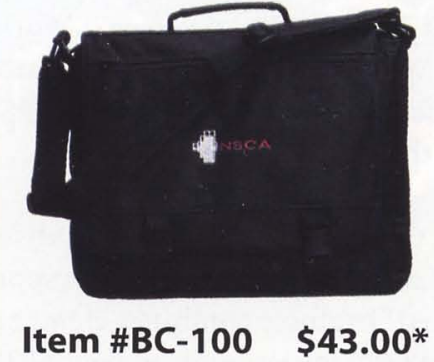

National Strength and Conditioning Association 1885 Bob Johnson Drive, Colorado Springs, CO 80906 • 800-815-6826 • www.nsca-lift.org 